DOI https://doi.org/10.18551/rjoas.2017-09.15

\title{
ISLAMIC MARKETER ETHICS AND ITS IMPACT ON CUSTOMER SATISFACTION IN THE ISLAMIC BANKING INSTITUTION: A CASE STUDY OF BANK MUAMALAT INDONESIA
}

\author{
Nuralam Inggang Perwangsa \\ Faculty of Administrative Science, University of Brawijaya, Indonesia \\ E-mail : ing.nuralam@ub.ac.id
}

\begin{abstract}
The aim of this study is to know the influence of Islamic marketer ethics to customers' satisfaction of Bank Muamalat Indonesia (BMI). These ethics principally concern on Qur'an and Hadith which are the basic foundation of Islamic values in Islam. Through this study we also can use another perspective of giving customer satisfaction in Islamic way and find out that there is a causal relation between Islamic marketer ethics and customer satisfaction. The research method used is survey method with sampling method using purposive sampling. Data analysis using multiple linear regression. From the results, it is found that Islamic marketer ethics as independent variables simultaneously effect on customer satisfaction, while partially some of variables refuse the hypothesis
\end{abstract}

\section{KEY WORDS}

Islamic marketer ethics, Islamic values, customer satisfaction.

Islamic banking is banking activity that complies with sharia (Islamic law) and its practical application through the development of Islamic economics. Sharia prohibits riba, or usury, defined as interest paid on all loans of money (Farooq, 2009; Khan 2013). Investment in businesses that provide goods or services considered contrary to Islamic principles (e.g. pork or alcohol) is also haraam ("sinful and prohibited").In the late 20th century as part of the revival of Islamic identity (Usmani, 1998), a number of Islamic banks formed to apply these principles to private or semi-private commercial institutions within the Muslim community (Rammal and Zurbruegg, 2007; Saeed, 1996). In 2009, at least more than 300 banks dan 250 mutual funds around the world complying with Islamic principles (The Economist, 2009) and around $\$ 2$ trillion were sharia-compliant by 2014 (The Economist, 2014).

Although the notion of Islamic banking is relatively new, which is no more than two decades, it still attracts the attention of many investors around the world. From a strategic point of view, this novelty is profitable and unfortunate at the same time. Thus, on the positive side, being a new idea, sharia banking has the potential to attract new customers and consequently, increasing market share of banks (Hassan et al., 2008). Siddiqi (1980) and Shahul (2001) say that sharia banks as business institutions running on the basis of Islamic principles should not be directed to generate maximum profit. As a business institution Islamic banks should be directed to achieve success in the world and in the afterlife (Siddiqi, 1980, and Shahul, 2001). Sadeque (1980) defines a Sharia bank as a financial institution operating on the basis of Shariah principles and does not always use the instrument of interest in receiving funds or providing financing to third parties. Therefore, according to Suleiman (2000), Sharia banks must operate on the basis of Sharia principles in every activity and transactions conducted.

A study conducted by Turen (1996) on bank performance shows that sharia banks perform better than non-Islamic banks. Samad and Hassan (2009) found that sharia banks are more liquid and less risky than conventional banks. The results are different from Rashid and Nishat (2009) who found poor performance of sharia banks in the field of investor management, profit maximization and operating efficiency. However, Sumachdar \& Hasbi (2011) and Jaffar \& Manarvi (2011) both found that sharia banks performed better than conventional banks. Hasbi and Haruman (2011) also found that Sharia Banking performed well; reflect CAMEL on the Deposit Fund. Kuppusamy et al., (2010) using financial indicators 
and indicators of sharia profitability, found that Islamic banks have maintained a very good position and have become benchmark institutions. While Masruki et al. (2011) found that the profitability of conventional banks is higher than that of sharia banks, but Islamic banks are more liquid than conventional banks. Widagdo and lka (2008) used inter-temporal comparisons and interbank ratios to test bank performance and the results found no major differences between sharia banks and conventional banks.

\section{LITERATURE REVIEW}

The major of the marketing literatures generally agrees on the benefits derived by product or service providers, policy makers, social activists or even consumers. Most of the priorities are advantages for product or service providers or marketers (Walters, 1974; Mowen, 1995; Hoyer and Maclnnis, 2001; Schiffman and Kanuk, 2004; Suprapti, 2010). This is because the ultimate goal of any marketing activity is consumer satisfaction as well as the benefits gained (marketer); including in sharia marketing.

Sharia marketing is a business process and a way to market its process that puts forward values that glorify justice and honesty (Kartajaya and Sula, 2006). With sharia marketing, the whole process should not be in conflict with Islamic principles. Sharia marketing is also followed by its ethics. These ethics are the principle for a Shariah marketer in carrying out marketing functions. Saeed et al. (2001) argue that ethical based on Islamic values requires marketers in no circumstances to exploit customers or to be dishonest and deceptive. Ethics are the conventional rules of individual behavior in a civilized society, formal or civic order of birth to govern interpersonal relationships, in accordance with their respective social status (Ya'qub, 1985; Spence and Heekeren, 2005; Faisal, 2007). Schlegelmilch (1998) further argues that ethics is difficult to define because the fact that it cannot be measured directly and derives from many influences such as the influence of internal and external environments.

Marketing based on Islamic perspective can be defined as a process and strategy (hikmah) to meet the need through the halal products and services (tayyibat) by mutual consent and welfare (Falah) of both parties of buyer and seller to achieve material and the spiritual wealth in the world and the hereafter (Alom and Haque, 2011).

Kartajaya and Sula (2006) reveal 9 (nine) marketer's ethics, which will become the principles for Shariah marketers in carrying out marketing functions: 1) Have a spiritual personality (Takwa). Religious values are present in the midst of us when doing business transactions; 2) Be kind and sympathetic (Shidq). A Shariah marketer must behave; Very sympathetic, sweet-spoken, humble words; 3) Applies fairly in business (Al-'Adl). In modern business, fairness must be portrayed for all stakeholders, all must feel justice; 4) Be serving and humble (Khidmah). Service is the most important factor in a business. Whatever the core of our business, stakeholders must always be aware that their business is a service business; 5) Keeping promises and not cheating. A Shariah marketer, must be able to maintain the trust given to him as a representative of the company in marketing and promoting products to customers; 6) Honest and reliable (Al-Amanah). Sharia business does seem to be hard for those who are accustomed to cheating, but it is light for those who rarely cheat, as well as for professionals who commonly uphold moral values; 7) Do not negative (Su'uzh-zhann). No one entrepreneur should vilify other entrepreneurs, only motivate business competition; 8) Do not backbiting (Ghibah). For sharia marketers, ghibah is a futile act, and a waste of time. It would be better for him to spill all his time to work professionally; 9) Do not bribe (Risywah). In shariah, bribe is haraam, and bribe is included in the category of eating other people's treasures by vanity.

As the empirical study has been conducted by raising the issue of Islamic financial institutions (Omer, 1992, Rosly, 2005); Islamic marketing (Arham, 2010; Kalthom \& Ahmad, 2010; Sandikci, 2011); Islamic ethics (Hanafy and Salam, 1988; Metawa \& Almossawi, 1998); Ethical Marketing of Sharia (Saeed et al., 2001; Hassan et al., 2008); Consumer Satisfaction in Sharia Banks (Naser et al., 1999; Lone and Rehman, 2017; Lone et al., 2017); 
Customer Relationship Management (Nuralam, 2016) this study also rely on the ethics of Sharia marketers associated with customer satisfaction.

Crosby et al. (1990) says that contact between the marketer and the consumer is the foundation in a consumer's purchase decision. Theorists such as Shepherd (1999) add that companies should emphasize the process of such relationships as critical points in business. Furthermore, in a study conducted by Hassan et al. (2008) mentions the term Customer Relationship Advisor (CRA) as a representation of bank institutions associated with the consumer.

\section{METHODS OF RESEARCH}

The study used a quantitative research methods since the purpose is to explain the correlation among variables syariah marketer ethics (Kartajaya and Sula, 2006) on customer satisfaction. The objective of quantitative research is to develop and employ mathematical models, theories and hypotheses pertaining to phenomena (Given, 2008). The variables syariah marketer ethics are have a spiritual personality (Takwa), be kind and sympathetic (Shidq), Applies fairly in business (Al-'Adl), Be serving and humble (Khidmah), Keeping promises and not cheating, Honest and reliable (Al-Amanah), Do not negative (Su'uzhzhann), Do not backbiting (Ghibah), Do not bribe (Risywah).

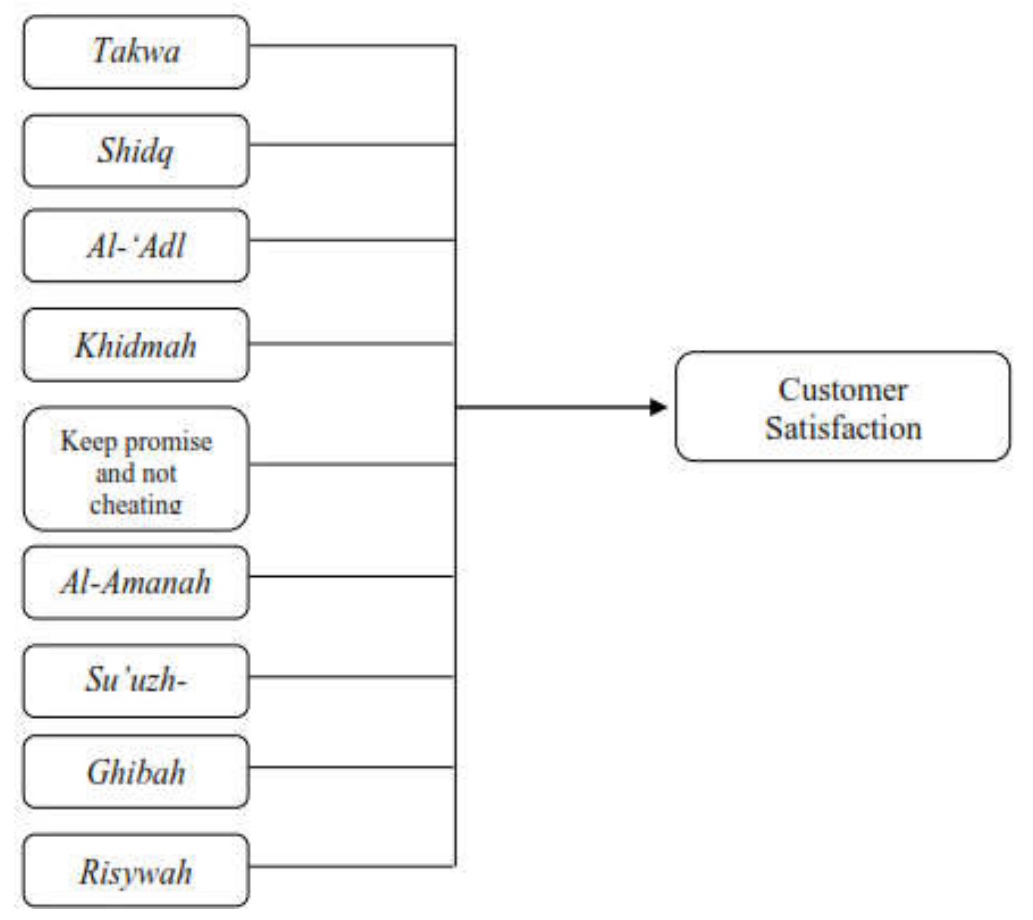

Figure 1 - Research Framework Source: (Adopted by Author, 2017)

The location of this research at Bank Muamalat Indonesia (BMI) Malang Branch, Jawa Timur. To look for these influences, there is a hypothesis to be tested. The hypothesis testing is done to test the influence of Shariah Marketer Ethics to the satisfaction (Kartajaya and Sula, 2006). To examine the relationship between these variables, regression analysis was used. The research framework is presented in Fig 1.

\section{RESULTS AND DISCUSSION}

This survey method conducted in the environment of Bank Muamalat Indonesia (BMI) Malang Branch. The sampling technique used is Purposive Sampling (Sekaran \& Bougie, 2016), which is the selection of the sample based on certain characteristics considered to be 
related to the previously known characteristic of the popover. According to Hoeber et al. (2017) purposive sampling is a sampling technique used in researches that prioritize the purpose of research rather than the nature of the population in determining the sample research. Then the respondents selected in this study is with the characteristics of 1) Has been use the products for approximately 6 months; 2) Has been use one of Bank Muamalat Indonesia's products. The sample used in this study was 136 respondents, referring to the population and purposive sampling.

The data used in this regression analysis is data obtained based on the results of questionnaires distributed to customers of Bank Muamalat Indonesia (BMI) Malang Branch with services perceived by customers or the reality encountered in the field. Based on the regression analysis, get the equation:

\begin{tabular}{|c|c|c|c|c|c|}
\hline No. & Independent Variable & $\begin{array}{l}\text { F test } \\
\text { (Overall } \\
\text { test) } \\
\text { Sig. } \mathrm{F}\end{array}$ & Alpha & $\begin{array}{c}\text { Influence on Customer } \\
\text { Satisfaction (Y) } \\
\text { Sig. F }<\text { Alpha }\end{array}$ & Hypothesis \\
\hline 1 & Independent Variable (X1-X9) & 0.000 & 0.05 & Significant & Supported \\
\hline No. & Independent Variable & $\begin{array}{l}\text { T test } \\
\text { (Partial } \\
\text { test) } \\
\text { Sig. }\end{array}$ & Alpha & $\begin{array}{l}\text { Influence on Customer } \\
\text { Satisfaction (Y) } \\
\text { Sig. < Alpha }\end{array}$ & Hypothesis \\
\hline 1 & $\begin{array}{c}\text { Have a spiritual personality } \\
(\text { Takwa })\left(\mathrm{X}_{1}\right)\end{array}$ & 0.021 & 0.05 & Significant & Supported \\
\hline 2 & $\begin{array}{l}\text { Be kind and sympathetic (Shidq) } \\
\left(\mathrm{X}_{2}\right)\end{array}$ & 0.000 & 0.05 & Significant & Supported \\
\hline 3 & $\begin{array}{l}\text { Applies fairly in business (Al-'Adl } \\
\qquad\left(\mathrm{X}_{3}\right)\end{array}$ & 0.828 & 0.05 & Significant & $\begin{array}{c}\text { Not } \\
\text { Supported }\end{array}$ \\
\hline 4 & $\begin{array}{c}\text { Be serving and humble } \\
(\text { Khidmah })\left(\mathrm{X}_{4}\right)\end{array}$ & 0.001 & 0.05 & Significant & Supported \\
\hline 5 & $\begin{array}{c}\text { Keeping promises and not } \\
\text { cheating }\left(X_{5}\right)\end{array}$ & 0.148 & 0.05 & Significant & $\begin{array}{c}\text { Not } \\
\text { Supported }\end{array}$ \\
\hline 6 & $\begin{array}{c}\text { Honest and reliable (Al-Amana) } \\
\left(\mathrm{X}_{6}\right)\end{array}$ & 0.019 & 0.05 & Significant & Supported \\
\hline 7 & $\begin{array}{c}\text { Do not negative (Su'uzh-zhann } \\
\qquad\left(X_{7}\right)\end{array}$ & 0.193 & 0.05 & Significant & $\begin{array}{c}\text { Not } \\
\text { Supported }\end{array}$ \\
\hline 8 & $\begin{array}{c}\text { Do not backbiting (Ghibah } \\
)\left(X_{8}\right)\end{array}$ & 0.749 & 0.05 & Significant & $\begin{array}{c}\text { Not } \\
\text { Supported }\end{array}$ \\
\hline 9 & $\begin{array}{c}\text { Do not bribe (Risywah } \\
)\left(\mathrm{X}_{9}\right)\end{array}$ & 0.090 & 0.05 & Significant & $\begin{array}{c}\text { Not } \\
\text { Supported }\end{array}$ \\
\hline
\end{tabular}

Source: Adopted by Author, 2017.

Based on the equation of regression analysis result, the interpretation obtained:

1. The higher value on the variables $X_{2}, X_{3}, X_{4}, X_{6}$, and $X_{9}$, the higher the Satisfaction (Y) felt by the customers of Bank Muamalat Indonesia (BMI) Branch Malang. In other words, the relationship of these variables is positive and unidirectional.

2. Otherwise the higher value on the variables $X_{1}, X_{5}, X_{7}$, and $X_{8}$, the lower the Satisfaction (Y) felt by the customers of Bank Muamalat Indonesia (BMI) Malang Branch. In other words, the relationship of these variables is negative and contradictory.

3. Coeffisient of determination (Adjusted $R$ Square) of 0.469 which means the variable $\mathrm{X}_{1}$ $\mathrm{X}_{9}$ able to explain the model of $46.9 \%$ while the rest $(53.1 \%)$ is explained by other variables that are not contained in this regression model.

4. F-test (overall test). It is known that the significance level of 0.000 and smaller than 0.05 $(0.000<0.05)$, it can be concluded that the independent variables $\left(X_{1}-X_{9}\right)$ simultaneously affect the dependent variable $(Y)$. The relationship between $\mathrm{X}_{1}-\mathrm{X}_{9}$ and $\mathrm{Y}$ variables can be seen on the correlation coefficient (R), which is positive is 0.710 which means the relationship of the variable is unidirectional and strong. Where the higher the ethics of sharia market, the higher the level of satisfaction.

5. T-test (partial test). Based on the number of significance can be seen that there are independent variables that partially significant effect on satisfaction, if significance $<0.05$, 
but there is also a partial no significant effect on satisfaction, if significance $>0.05$.

6. The rejection of the hypothesis is based on the lack of perceived variables by the customer. Although the performance of these variables is good enough, but customers can not feel the impact directly. This is due to the lack of customer understanding about the ethics of sharia marketers run by Bank Muamalat Indonesia (BMI) Malang Branch. What has been felt directly by customers of Bank Muamalat Indonesia (BMI) Malang Branch is the services provided by the bank, so that the ethics of sharia marketers with respect to services that is Variable $X_{2}$ (behave kindly and sympathetic) Sharia is a very perceived syariah marketer By the customer directly.

\section{RESEARCH LIMITATION}

The existence of an opportunity error of the use of a particular indicator to measure the variables concerned because of the difficulty of drawing firm limits between variables with each other. This research is only conducted limited to the Bank Muamalat Indonesia (BMI) Branch Malang, so it needs to expand the larger scope of research to get A better picture. The nine ethics of sharia marketers used in this study are only able to explain the model of $46.9 \%$ which means that the rest are explained other variables not included in the study.

\section{CONCLUSION AND RECOMMENDATION}

It is concluded that Shariah Marketer Ethics such as have a spiritual personality (Takwa) $\left(\mathrm{X}_{1}\right)$, be kind and sympathetic (Shidq) $\left(\mathrm{X}_{2}\right)$, Applies fairly in business (Al-'Adl) $\left(\mathrm{X}_{3}\right)$, Be serving and humble (Khidmah) $\left(\mathrm{X}_{4}\right)$, Keeping promises and not cheating $\left(\mathrm{X}_{5}\right)$, Honest and reliable (Al-Amanah) $\left(\mathrm{X}_{6}\right)$, Do not negative (Su'uzh-zhann) $\left(\mathrm{X}_{7}\right)$, Do not backbiting (Ghibah) $\left(\mathrm{X}_{8}\right)$, Do not bribe (Risywah) $\left(\mathrm{X}_{9}\right)$ simultaneously affect the satisfaction of customers of Bank Muamalat Indonesia Malang Branch $(Y)$. Then, variable of have a spiritual personality (Takwa) $\left(\mathrm{X}_{1}\right)$, be kind and sympathetic (Shidq) $\left(\mathrm{X}_{2}\right)$, Be serving and humble (Khidmah) $\left(\mathrm{X}_{4}\right)$, Honest and reliable (Al-Amanah) $\left(\mathrm{X}_{6}\right)$ Partially significant effect on customer satisfaction of Bank Muamalat Indonesia (BMI) Malang Branch. Variable Shariah Marketer Ethics "be kind and sympathetic (Shidq) $\left(\mathrm{X}_{2}\right)$ ") is the dominant influence Customer satisfaction of Bank Muamalat Indonesia (BMI) Malang Branch (Y).

In our discussion this ethical behavior of Islam will have a major impact on the development and scheduling of buyer-marketer relationships. Therefore, Islamic banks that value the importance of long-term relationships with their customers, must reach an environment where the potential for unethical behavior is minimal. Thus, management should follow-up on the following: (1) The need to create, communicate and apply the ethical code of sharia. Employees should know whether it is necessary. When it happens, it is very important to be informed of the punitive action taken against the offender; (2) Sharia ethics code should be the basis of ongoing training related to ethical dilemmas. Sharia bank management needs to be updated on sales training programs where sales managers can present salespeople with several different ethical scenarios and ask each of them; (3) Sharia bank managers should try to communicate with the marketing of their products / services, assist and guide them to specifically view their daily sales activities from the perspective of sharia ethics and its various activities, not just the results achieved (sales volume).

From this Islamic banks in an ethical manner guided by the value of Islam (sharia) as the main reference source, there is gun to the records of local Islamic banks still cannot achieve the goals of society and the environment. Some community groups as consumers, are expecting the quality of sharia banks can increase. This is evident from the empirical studies expressed in this book that highlight such as 1) speed and perception over time; 2) Best practices in use (professionalism / corporate governance); 3) Transparency of transactions and financial reporting; needs to be improved so that consumers as customers feel satisfied with the sharia banking system. 


\section{ACKNOWLEDGMENTS}

This research is conducted by a joint research team organized by Faculty of Administrative Science (FIA) and Research Institutions and Community Service (BPP-FIA), Universitas Brawijaya. Members of the team are Inggang Perwangsa Nuralam (Faculty of Administrative Science) and Students of the Faculty of Administrative Science. The research team expresses their gratitude to the Director of Research Institutions and Community Service (BPP-FIA), Universitas Brawijaya who grants a collaborative Research Grant for budget year 2017.

\section{REFERENCES}

1. Alom, M. M., \& Haque, M. S. (2011). Marketing: an Islamic perspective. World Journal of Social Sciences, 1(3), 71-81.

2. Arham, M. (2010). Islamic perspectives on marketing. Journal of Islamic Marketing, 1(2), 149-164.

3. Cooper, R.W. and Frank, G.L. (2002) "Ethical Challenges in the Two Main Segments of the Insurance Industry: Key Considerations in the Evolving Financial Services Marketplace", Journal of Business Ethics, 36: 5-20.

4. Crosby, L. A., Evans, K. R., \& Cowles, D. (1990). Relationship quality in services selling: an interpersonal influence perspective. The journal of marketing, 68-81.

5. Faisal. (2007). Tekanan Pengaruh Sosial dalam menjelaskan Hubungan dalam Moral Reasoning terhadap keputusan Auditor. Jurnal Akuntansi dan Keuangan Negara, Vol 4(1) Juni: 25-46.

6. Farooq, Mohammad Omar. (2009). The Riba-Interest Equation and Islam: Reexamination of the Traditional Arguments. Global Journal of Finance and Economics, Vol. 6, No. 2, pp. 99-111

7. Given, Lisa M. (2008). The Sage encyclopedia of qualitative research methods. Los Angeles, Calif.: Sage Publications. ISBN 1-4129-4163-6.

8. Hanafy, A. A. \& Salam, H. (1988). Business ethics: an Islamic perspective. Proceeding of the Seminar on Islamic Principles of Organizational Behaviour, IIIT, Herndon, USA

9. Hasbi, H., and Haruman, T. (2011). Banking: According to Isalmic Sharīah Concepts and its performance in Indonesia. International Review of Business Research Papers, 7 (1), 60-76.

10. Hassan, Abul., Abdelkader Chachi., and Salma Abdul Latiff. (2008). Islamic Marketing Ethics and Its Impact on Customer Satisfaction in the Islamic Banking Industry. JKAU: Islamic Econ., Vol. 21 No. 1, pp: 27-46.

11. Hoeber, O., Hoeber, L., Snelgrove, R., \& Wood, L. (2017). Interactively Producing Purposive Samples for Qualitative Research using Exploratory Search. In SCST@ CHIIR (pp. 18-20).

12. Hoyer, W. D. \&MacInnis, D. J. (2001). Consumer behaviour (2nd ed.). New York: Houghton Mifflin.

13. Jaffar, M., and Manarvi, I. (2011). Performance comparison of Islamic and conventional banks in Pakistan. Global Journal of Management and Business Research, 2 (1), 60-66.

14. Kalthom, Abdullah \& Mohd Ismail Ahmad. (2010). Compliance to Islamic marketing practices among businesses in Malaysia. Journal of Islamic Marketing, 1(3), 286-297.

15. Kartajaya, Hermawan., M. Syakir Sula. (2006). Syariah Marketing. Bandung: PT Mizan Pustaka.

16. Khan, Muhammad Akram (2013). What Is Wrong with Islamic Economics?: Analysing the Present State and Future Agenda. Edward Elgar Publishing. ISBN 9781782544159

17. Kuppusamy, M., Salman, A., and Samudhram, A. (2010). Measurement of Islamic banks performance using a Sharīah Conformity and Profitability Model. International Association for Islamic Economics, 13 (2), 35-48. 
18. Lone, Fayaz Ahmad and Rehman, Awais Ur. (2017). Customer Satisfaction in FullFledged Islamic Banks and Islamic Banking Windows: A Comparative Study. Journal of Internet Banking and Commerce, Jan 2017, vol. 22, no. S7.

19. Lone, Fayaz Ahmad.; Ebraheem Mohamad Aldawood.; Ulfat Rashid Bhat (2017). Comparative Analysis of Customer Satisfaction Towards Islamic and Conventional Banking: An Empirical Study from Saudi Arabia. International Review of Management and Marketing, 2017, 7(1), 273-280.

20. Masruki, R., Ibrahim, N., Osman, E., and Wahab, H. A. (2011). Financial performance of Malaysian Founder Islamic Banks versus Conventional Banks. Journal of Business and Policy Research, 6 (2), 67-79

21. Metawa, S. A. \& Almossawi, M. (1998). Banking behaviour of Islamic bank customers: Perspectives and implications. International Journal of Bank Marketing, 16(7), 299-313.

22. Mowen, J. C., \& Minor, M. (1995). Consumer Behavior. 4-th ed. Jersey: Prentice Hall.

23. Naser, K., Jamal, A. \& Al-Khatib, L. (1999). Islamic banking: A study of customer satisfaction and preferences in Jordan. International Journal of Bank Marketing, 17(3), 135-150.

24. Omer, H. S. H. (1992). The implications of Islamic beliefs and practice on the Islamic financial institutions in the UK: Case study of Albaraka International Bank UK. Unpublished Doctoral Thesis, Loughborough University.

25. Nuralam, I. P. (2016). Creating Customer Relationship Management Based On Islamic Values: A Case Study Of Pt. Bank Muamalat Indonesia Tbk. Russian Journal of Agricultural and Socio-Economic Sciences, 58(10).

26. Rammal, H. G., \& Zurbruegg, R. (2007). Awareness of Islamic banking products among Muslims: The case of Australia. Journal of Financial Services Marketing, 12(1), 65-74.

27. Rashid, M., and Nishat, A. (2009). Disparity of performance indicators of Islamic banks: study on Bangladesh. International Journal of Business and Management, Vol.4.No.8, 52-72.

28. Rosly, Saiful Azhar. (2005). Critical issues on Islamic banking and financial markets. Kuala Lumpur: Dinamas.

29. Sadeque, M. (1980). Components of Islamic Banking. Ins, Thought of Islamic Banks. Dhaka. Bangladesh

30. Saeed, A. (1996). Islamic Banking and Interest: A Study of the Prohibition of Riba and its Contemporary Interpretation. Leiden, Netherlands: E.J.Brill.

31. Saeed, M., Ahmed, Z. U., \& Mukhtar, S. M. (2001). International marketing ethics from an Islamic perspective: A value-maximization approach. Journal of Business Ethics, 32(2), 127-142.

32. Samad, A. and Hassan, K. (2009). The Performance of Malaysian Islamic Bank during 1984-1997: an exploratory research. International Journal of Islamic Financial Service $1(3)$.

33. Sampurno, 2011. Manajemen Pemasaran Farmasi, Yogyakarta: Gadjah Mada University Press.

34. Sandikci, O. (2011). Researching Islamic marketing: Past and future perspectives, Journal of Islamic Marketing, 2(3), 246-258.

35. Schiffman, L. G. \& Kanuk, L. L. (2004). Consumer behaviour (8th ed.). New Jersey: Prentice Hall.

36. Schlegelmilch, B. B. (1998). Marketing Ethics: An International Perspective. London: International THomson Business Press.

37. Sekaran, U., \& Bougie, R. (2016). Research methods for business: A skill building approach. John Wiley \& Sons.

38. Shahul, H.M.I. (2001). Different Worldview Needs Different Accounting. Paper presented at IIUM International Conference of Accounting I, Kota Bahru, Kelantan, Malaysia.

39. Shepherd, P. R., \& Kahn, B. B. (1999). Glucose transporters and insulin actionimplications for insulin resistance and diabetes mellitus. New England Journal of Medicine, 341(4), 248-257.

40. Siddiqi, N. (1980). The Issues of Islamic Economics. Lahore, Pakistan 
41. Spence, E. H., \& Heekeren, B. V. (2005). Advertising Ethics. New Jersey: Pearson Education, Inc.

42. Suleiman, N. (2000). Corporate Governance of Islamic Bank. At http://www.nzibo.com/lB2/nmsuleiman.pdf. Retrieved at 5th Agust 2017.

43. Sumachdar, Endang dan Hariandy Hasbi. 2010. Financial Performance Analysis for Islamic Rural Bank to Third Party Funds and The Comparation with onventional Rural bank in Indonesia. International Conference on Business and Economics research Vol. 1 (2011).

Suprapti, N. W. S. (2010). Perilaku konsumen [Malay manuscript]. Bali: Udayana University Press.

44. The Economist. (2009). "Sharia calling". The Economist. The Economist Newspaper Limited 2009-11-12. http://www.economist.com/node/14859353. Retrieved 15 September 2017.

45. The Economist. (2014). "Islamic finance: Big interest, no interest". The Economist. The Economist Newspaper Limited. Sep 13, 2014. https://www.economist.com/news/financeand-economics/21617014-market-islamic-financial-products-growing-fast-big-interest-nointerest. Retrieved 15 September 2017.

46. Turen, S. (1996). Performance and risk analysis of the Islamic Banks: The case of Bahrain Islamic bank. J.KAU: Islamic Economics, 8, 3-14.

47. Usmani, M. T. (1998). An Introduction to Islamic Finance. Karachi: Idaratual Maarif.

48. Walters, C. G. (1974). Organizational behaviour: Human behaviour at work (9th ed.). New Delhi: Tata McGraw Hill.

49. Widagdo, A. K., \& Ika, S. R. (2008). Analisis Perbandingan Kinerja Keuangan Bank Syariah dengan Bank Konvensional. Jurnal Ekonomi dan Bisnis, UNS.

50. Ya'qub, D. H. (1985). Etika Islam: Pembinaan Akhlaqulkarimah (Suatu Pengantar) (3 ed.). Bandung: CV. Diponegoro. 